Témoigner Témoigner. Entre histoire et mémoire

Getuigen Revue pluridisciplinaire de la Fondation Auschwitz

122 | 2016

Révisionisme et négationisme

\title{
Susanne Buckley-Zistel, et al., Transitional Justice Theories
}

\section{Hanna Teichler}

\section{Q OpenEdition \\ 1 Journals}

\section{Electronic version}

URL: https://journals.openedition.org/temoigner/4793

DOI: 10.4000/temoigner.4793

ISSN: 2506-6390

Publisher:

Éditions du Centre d'études et de documentation Mémoire d'Auschwitz, Éditions Kimé

\section{Printed version}

Date of publication: 2 May 2016

Number of pages: 182-184

ISSN: 2031-4183

\section{Electronic reference}

Hanna Teichler, "Susanne Buckley-Zistel, et al., Transitional Justice Theories", Témoigner. Entre histoire et mémoire [Online], 122 | 2016, Online since 30 September 2021, connection on 04 January 2022. URL: http://journals.openedition.org/temoigner/4793 ; DOI: https://doi.org/10.4000/temoigner.4793

This text was automatically generated on 4 January 2022.

Tous droits réservés 


\title{
Susanne Buckley-Zistel, et al., Transitional Justice Theories
}

\author{
Hanna Teichler
}

\section{REFERENCES}

Buckley-Zistel, Susanne, Teresa Koloma Beck, Christian Braun, Friederike Mieth, Transitional Justice Theories, London, Routledge, 2014, 228 p.

1 On 11 June 2008, Canadian Prime Minister Stephen Harper claimed his nation's public attention for delivering an official apology on behalf of the federal government. This apology was directed at the indigenous populations of Canada, the First Nations. The Canadian Head of State publically apologized for the mistreatment of the indigenous under colonial rule, in particular for the so-called Indian Residential School System. The system was aimed at eradicating any notions of indigeneity within the children of First Nations descent which were forcibly removed from their family and kin. Indigenous customs and languages were prohibited, and cultural re-education in a Christian manner frequently unfolded under duress. High death tolls as well as heinous living conditions were part of the residential school experience. This aspect of colonial rule never quite reached public attention in Canada and remained largely absent from the Canadian national narrative. However, continuous lobbying and increasing legal pressure had finally forced the government's (and churches') hands to address the matter publically: a Settlement Agreement not only regulated compensations and reimbursement for the victims, but it also envisaged the creation of a Truth and Reconciliation Commission (T R C) in order to guide a path towards national reconciliation with the indigenous populations. The T R C of Canada commenced its work in 2010 and has just published its Final Report.

2 The Canadian case of coming to terms with historical legacies of state violence is just one among a plethora of examples where mechanisms of transitional justice have been put to use. The discourses of transitional justice have claimed the international stage in 
recent years. The rising demand for structures enabling political and social change within nations is reflected in the variety of cases implementing such mechanisms. The most famous example, in terms of international attention, is certainly the South African Truth and Reconciliation Commission under the primacy of Arch bishop Desmond Tutu and Nelson Mandela, which sought to guide South Africa's transition from authoritarian Apartheid rule to democracy. In a similar vein, Chile established a commission to rework the legacies of dictatorship. In Rwanda, ethnical cleansings and genocide where also addressed through the framework of such a commission. Furthermore, the United Nations declared 2009 to be the International Year of Reconciliation. This short and by no means exhaustive list shows how prominent the discourses of transitional justice and reconciliation have become in recent years.

3 The multifaceted nature of cases is exactly the point of entrance that Susanne BuckleyZistel, Teresa Koloma Beck, Christian Braun, and Friederike Mieth have chosen for their collection of essays. In their introduction, the authors argue that there has been an increase in examples, but not in attempts to theorize the concept of transitional justice. They show that the denotation "transitional justice" is frequently used, but cannot be regarded as more than an umbrella term: the notion oscillates between memorial projects subverting dominant accounts of national history, and the harnessing of national narratives for political purposes. It is used in order to restore the victims' dignity while at the same time negotiating monetary compensation. Transitional justice is called upon when nothing less than a political and a social transition in light of a (historical) conflict appears to be in order. Yet, the concept has also left its traditional realm of changing political regimes and has migrated to seemingly established democracies - see for example the recent Canadian case. Apart from having become an en vogue concept in terms of international politics, it has gradually made its way into the (post)colonial sphere.

4 In the midst of conceptual proliferation, Buckley-Zistel and her fellow editors call for a furthering of theoretical approaches towards transitional justice. They direct our attention at the need to refine our understanding of the process. Suggesting that the multitude of cases and case studies has led the field of inquiry to grow too quickly in order for it to be theoretically mapped (see p.3), they advertise for severing the concept from its practice and performance. It is the aim of this essay collection to establish a theoretical framework through which universal features and mechanisms of transitional justice can be described. In a nutshell, Buckley-Zistel et al. seek to answer the question whether transitional justice is indeed an all-powerful remedy to "cure" national and social frameworks of the evil of discrimination and conflict, and whether it is "as all-encompassing as proponents would have us believe" (p. 4). In this vein, the contributions in this essay collection focus, on the one hand, on the expectations that we have of transitional justice and, on the other, what it actually should be able to bring about.

5 If one takes a look at the name of the concept itself and its historical development in research - as the editors did in the introduction - the vastness of possibilities of what transitional justice should mean and entail, becomes obvious. The first part transitional - already raises several questions: what kind of society model stands at the end of transitional justice processes, the editors ask. Furthermore, the second part of the term - justice - refers to a wide range of different, and at times competing, interpretations of justice: punitive, corrective, restorative, reparative, and distributive. 
The essays gathered by Buckley-Zistel and her colleagues reflect the multitude of possible approaches, but also show the difficulties of defining transitional justice. The collection is divided into two parts: part one is centred around the trajectories that transitional justice may undertake (theoretically), while part two stresses the notion's flaws and limits.

The contributions all work their way towards conceptualizing transitional justice from various angles. Wendy Lambourne and Nevin T. Aiken discuss the restorative potential of transitional justice: on a societal level, related processes such as commissions, hearings, reports, and reconciliation events, may foster relationships between antagonizing parties. Transitional justice processes indeed affect national narratives and identities because they address well-established, often negative, perceptions and stereotypes which characterize hardened conflicts. They are educational in nature, entailing learning processes at all societal levels. Kora Andrieu and Lisa J. Laplante further argue that transitional justice unfolds through the reiteration and performance of normative foundations of a society. It recalibrates notions of justice, for it opens up a wide range of possibilities to move beyond strictly legal interpretations. Laplante focuses on the issue of reparations, just as Thomas Obel Hansen, who analyzes how and why transitional justice has become an international norm, a "toolbox" to resort to in times of national crises. All authors stress the strong moral components of the process, emphasizing the primarily "Western" viewpoints that underpin it.

7 The second part explores the conceptual limits of transitional justice. Jelena Subotic discusses the constant tension between the global norm of transitional justice, and the local requirements and specificities. A concept as elusive as transitional justice, she contends, will always be "customized" by local beneficiaries, and, as such, undermine attempts to pin it down. Susanne Buckley-Zistel's article follows a similar trajectory when she underlines that transitional justice narratives may become as hegemonic and monolithical as the ones they seek to destabilize. By recalibrating "what can be said and how" (p.12), transitional justice processes unfold their discursive power, (re)producing an "inside" and an "outside", and thus rearranging the parameters of belonging and exclusion. Transitional justice in this way becomes a social force of its own right.

Magdalena Zolkos and Teresa Koloma Beck direct our attention towards memory politics. Zolkos links memory work and collective trauma, thereby underlining the therapeutic aspects of reworking difficult historical and political legacies. Yet, the constant reiteration and performance of traumatic mnemonic narratives possibly leads to the re-traumatization of victims and survivors, instead of being a cure. Koloma Beck's article then focuses on physical trauma: despite their focus on language and speech, the author argues, processes of transitional justice also deeply affect "body memories acquired under violent rule" (p. 186) such as torture, fear, and suffering. Carolina Olarte and Hannah Franzki conclude the collection by highlighting that, even though it is often considered as an "apolitical" programme, transitional justice is in fact driven by political agendas, and can effectively alter power relations. More specifically, and this is a point made throughout the collection, transitional justice promotes the dominant Western interpretation of political reality (e.g. liberal democracy).

9 All in all, this very rich collection of essays proves to be a helpful tool in making your way through conflict solving strategies on a state and society level. Although much has 
been said about transitional justice and its practices, this has indeed only led to revisiting prevailing theoretical regimes. The Canadian case, for example, is worth being discussed through the lenses that the various articles provide: What kind of transition is actually required, since Canada is already an established democracy? Which interpretation of justice is proliferated through Canada's T R C when legal questions are severed from the project of national reconciliation? Who benefits from processes of transitional justice? Are transitional justice and reconciliation not simply a cloak for furthering the national project and hindering claims of indigenous sovereignty? Which normative regimes are actually at work within transitional justice, and do they perhaps promote assimilation, rather than "new beginnings on an equal level"? With the help of this collection, case studies such as the Canadian one can be approached through more theoretically refined frameworks.

However, as a reader and literary scholar, I would have been highly intrigued by a third part that, through specific case studies, would bridge the gap between theory and practice. Moreover, the volume lacks perhaps an analysis of cultural productions. Transitional justice processes have in fact inspired multifaceted artistic engagements with the issues in question, and these productions have in their turn worked as triggers to redefine transitional justice. Therefore, an approach on culture, as a seismograph of the various interest involved in these highly political and controversial processes, would have enlarged the scope of this important, resourceful attempt to conceptualize transitional justice.

\section{AUTHORS}

\section{HANNA TEICHLER}

Goethe University Frankfurt am Main 